\title{
Unlocking Spirituality at Workplace through Islamic Work Ethics: Analyzing Employees' Performance in Islamic Banks
}

\author{
Muhammad Sarmad ${ }^{1 *}$, Rimsha Iqbal ${ }^{2}$, Muhammad Anwar Ali ${ }^{3}$, Ayaz-ul-Haq ${ }^{4}$ \\ ${ }^{1}$ Assistant Professor, Riphah International University, Islamabad, Pakistan \\ 2 Associate Lecturer, Fatima Jinnah Women University, Rawalpindi, Pakistan \\ ${ }^{3}$ Branch Manager, Dubai Islamic Bank, Rawalpindi, Pakistan \\ ${ }^{4}$ Assistant Professor, University of Central Punjab, Rawalpindi, Pakistan
}

\section{Keywords}

Spirituality at Workplace Islamic Work Ethics (IWE)

Employees' Performance

Islamic Banks

Received: 18 April 2018

Accepted: 08 September 2018

\begin{abstract}
This study reveals the worth of spirituality at workplace by considering its factors (inner life, meaningful work and sense of community) in the context of IWE for investigating employees' performance. The data was collected from 347 serving middle line managers of Islamic banks across major cities of Pakistan. SPSS 21 was used to analyze the data through correlation, multiple regression and moderated regression analysis with appropriate data normality and independence. The results revealed that two determinants of spirituality at workplace (meaningful work and sense of community) create significant positive impact on employees' performance. On the contrary, the third determinant (inner life) exhibits insignificant effect on employees' performance. It is also established that IWE do not moderate the relationship between inner life and employees' performance; however, a moderation effect of IWE is found in the relationship between meaningful work and employees' performance as well as sense of community and employees' performance. Thus, implications for Islamic banks have been discussed in particular and other organizations in general to uphold spirituality at workplace and IWE for sustaining performance standards across all quarters.
\end{abstract}

KAUJIE Classification: H54, L25, T4

JEL Classification: N3, M5

(C) 2018 JIBM. All rights reserved.

\section{INTRODUCTION}

Modern era is overwhelmed by social, environmental and economic problems resulting from greed for self-interest and lack of compassion and love for others. Such huge problems pushed individuals for a rehabilitated search of peace, harmony and to find fundamental spiritual journey (Cacioppe, 2000). Spiritual approach emphasized that people work not only

*Corresponding author: Muhammad Sarmad

†Email: muhammad.sarmad@riphah.edu.pk 
with their hands, but also with involvement of their heart and spirit (Ashmos \& Duchon, 2000). In recent years, organizations have witnessed most important changes in their organizational structure and design. Such changes triggered work environment in which employees feel low level of sense of community. As a result, organizations face problems in building suitable work community among co-workers and an environment where employees can exhibit their overall capacity (Brandt, 1996; Driver, 2005).

Petchsawanga and Duchan (2012) identified that workplace spirituality focuses on different activities at work considering meaningfulness, personal development, joy at work, compassion, trust, commitment, honesty and well-being of employees. Similarly, Ashmos and Duchon (2000) revealed that inner life, meaningful work and sense of community are three important constructs of workplace spirituality. Scholars of past empirical studies indicate that workplace spirituality, generally known as spirituality at workplace, is brought into practice through different programs by many successful organizations e.g., DuPont, At \& T, Apple Computers, Chase Manhattan Bank (Cavanagh, 1999), World Bank (Laabs, 1995), Ford Motor Company, Hawlett-Packard and Toms of Marine (Burack, 1999). However the notion of workplace spirituality in developing countries like Pakistan which are infested in illiteracy and business intolerance is still outlandish.

Zafar (2010) investigated workplace spirituality and religiosity in Pakistani organization. He found workplace spirituality in practice to some extent, but failed to find any organization where workplace spirituality was being followed in true letter and spirit. Ajmal and Irfan (2014) revealed that significant positive association existed between IWE and job performance. Wahab (2017) argued to consider IWE with personality traits of Muslim employees, rather that of the Non-Muslims employees. Gocen and Ozgan (2018) supported to extend the significance of spirituality at workplace in context of IWE for better performance. Thus, implementation of IWE through spirituality at workplace is pivotal for performance of individuals.

Since decades, the concept of workplace spirituality has engrossed massive consideration in different sectors of economy and specifically in banking industry. In spite of the efforts made at implementing the workplace spirituality, it is difficult for the organization to improve the overall performance of their employees (Garcia-Zamor, 2003; Usman \& Danish, 2010). On the other hand, IWE provide a standard to all the followers of Islam by advocating the principals of work environment (Ali \& Al-Owaihan, 2008). The Holy Qur'ān also emphasized the standing of ethics frequently as "You are the best nation has been raised up for mankind; you enjoin right conduct, forbid evil and believe in Allah" (3:110). Thus banking sector in Pakistan, being an Islamic country, has witnessed a rapid shift towards implementation of Islamic Sharī'ah laws. Al-Arimi, Masrom, and Mahmood (2016) argued that moderating role of IWE while considering the association of workplace spirituality has not yet received considerable attention. Therefore, taking this opportunity as a gap, the present study investigated the impact of workplace spirituality on employees' performance while considering IWE as moderator in Islamic banking industry.

The said research gap has been explored under Virtue Ethics theory by Aristotle (Sherman, 1989) as overarching theory in this study, which is further augmented by Expectancy 
theory of Motivation (Vroom, 1964). As Rachels and Rachels (1993) argued that Aristotle was the strongest followers of virtue ethics theory who suggested some ethical traits that every individual should have e.g., self-control, modesty, fairness, justice, friendliness, generosity, loyalty, self-confidence and tolerance. This study is based on the principals of 'virtue ethics theory' by using the moderating role of IWE, as Islam ponders both virtuous ethics and ethical actions in combination (Mohammed, 2005). In Islam, every Muslim must perform in accordance with certain ethical characteristics that are sourced from Qur'ān and Sunnah. Moreover, 'expectancy theory of motivation (Vroom, 1964) provides a deeper understanding of work related variables such as job performance, job effort, morale, needs fulfillment and motivation for effective performance (Wabba \& House, 1974; Vroom, 1964) duly pursued under IWE.

Consequently, this study intends to contribute to the existing body of knowledge by bridging moderating role of IWE across spirituality at workplace and employees' performance. This clarifies the misconception of spirituality at workplace to be treated as religious construct, rather to be considered as performance oriented mechanism across workforce (Gocen \& Ozgan, 2018). Similarly, the contribution of present study to Islamic banking literature is two-fold. First, this study provides a framework that will be helpful in knowing the influence of IWE in strengthening the association of workplace spirituality and employee's performance in Islamic banking industry in Pakistan. Secondly this research could also provide useful insights for policy makers and banking professionals to make strategies to device workplace spirituality (Ozgan, 2017) in accordance with IWE, so as to increase employee's performance at workplace.

Therefore, as various scholars emphasized that workplace spirituality can play a pivotal role in achieving employees' performance in banking sector of Pakistan, the primary objective of present study is to determine the impact of inner life, meaningful work and sense of community as factors of workplace spirituality on employees' performance. Moreover, as Islamic principles completely cover all prospects of life including working in any organization; thus, the present study also aims to investigate the moderating role of IWE on determinants of workplace spirituality and employees' performance relationship.

\section{LITERATURE REVIEW}

\section{Spirituality at Workplace}

Workplace spirituality is a philosophy used in various contexts that pursues to unfold and identify relationship of meaning, interconnectedness and a sense of balance within life at workplace (Nandan-Prabhu, Rodrigues, \& Kumar, 2017). In academics, workplace spirituality concept has been considered in many ways making it hard to find a comprehensive definition (Tischler, Biberman, \& McKeage, 2002). Ashmos and Duchon (2000) defined workplace spirituality as "the appreciation that employees have an inner life that nurtures and is nurtured by meaningful work that takes place in the context of community". Therefore, in present study, inner life, meaningful work and sense of community are utilized as determinants of workplace spirituality because these three independent elements have been 
tested in connection of different variables (Duchon \& Plowman, 2005; Rego \& Cunha, 2008; Rego, Cunha, \& Souto, 2007) and provide stingy approach in consideration of job performance of employees.

\section{Inner Life and Employee's Performance}

Inner life establishes a significant aspect of workplace spirituality. Nandan-Prabhu et al. (2017) stated that the notion of inner life is stimulated by the certainty that every individual comes at workplace along with all aspects of character. Consequently, employees expect freedom and options at workplace to express every aspect of their life. This concept of spirituality pursues countenance of spiritual aspects of individuals at workplace. Similarly Ashmos and Duchon (2000) considered the spirituality is the eld of inner awareness where individuals express themselves as they work with a feeling of interconnectedness, harmony and oneness.

Malphurs (2004) indicated that a person is not supposed to work for any institution either sacred or secular, whose institutional values are not shared by him or her. However, McCarty (2007) indicated that due to workplace spirituality (inner life) the overall confidence and productivity of employee increased that, in turn, resulted in decreased employee turnover. According to Altaf and Awan (2011), workplace spirituality is different from spirituality itself as it is the well-being of individuals in terms of spirituality at workplace including different factor which influence employees' satisfaction and performance. Therefore, based on previous discussed literature, following hypothesis is developed for further exploration.

H1: Inner life is positively related with employees' performance.

\section{Meaningful Work and Employee's Performance}

Nandan-Prabhu et al. (2017) maintains that significance of work upholds the dimension of spirituality at workplace known as meaningful work. This explains the degree of employees' understanding to consider their work valued and important for their own and others benefit. Therefore, the consideration of meaningful work is an exploration of self-worthiness, values and purpose. Many scholars focused on the worthiness of job activities of employees that are being performed on workplace. Morse and Weiss (1955) argued that meaningfulness at work implied that apart from a source of the livelihood, job of an employee is to pursue in-depth meaning in work to attain efficient performance. Thus, when work is considered as passion, it turns out to be more expressive and results in subsequent rise in overall productivity and assurance (Paloutzian, Emmons, \& Keortge, 2003; Reave, 2005).

Moreover, Petchsawang \& Duchon (2012) argued that when people work with full commitment and spirit, they nd meaning and purpose in their work which ultimately means that the workplace can be a place where people can express their whole or entire selves. Thus, while expressing human experience deeply, in the most cases, spiritual level resulted in reduction of stress, conict, and absenteeism, and also enhanced work performance (Krahnke et al. 2003) and employee's well-being and quality of life (Karakas 2009). Likewise Krishnakumar and Neck (2002) identified that workplace spirituality enhanced creativity, per- 
sonal fulfillment and commitment of employees, which led to increased employees' and organizational performance. Therefore, on the basis of aforementioned arguments following is hypothesized.

H2: Meaningful work is positively related with employees' performance.

\section{Sense of Community and Employee's Performance}

The third dimension of spirituality is sense of community which is also regarded as connectedness with colleagues at workplace and gaining spiritual growth and interconnectedness with others (Marques, 2005). Naylor et al. (1996) proposed community as an engagement of independent people that are dedicated to support and foster each other through participation in terms of body, mind, heart and soul.

According to McMillan and Chavis (1986), community means common faith and sense of belongingness among coworkers. Past empirical studies revealed that employees prefer the workplaces where they are comfortable in feeling as part of that community (Miller, 1998; Mirvis, 1997; Pfeffer \& Veiga, 1999). Shared sense of purpose and values trigger employees to unite as they can experience a strong feeling of connectedness (Chappell, 1993). Moreover, Fry (2013) argued that engagement of organizations in "high commitment workplace spirituality practices" provided benefits to both individual as well as organizations. In the same way, Duchon and Plowman (2005) stated that when employees exhibit a strong sense of belonging to a community, the overall performance of employees increased. Thus, based on aforesaid arguments following hypothesis is developed to explore the relationship of sense of community and employees' performance.

H3: Sense of community is positively related with employees' performance.

\section{Moderating Role of IWE between Inner Life and Employee's Performance}

IWE refer to a comprehensive concept covering all the aspects prevailing in organizational structure including commitment, team work, flexibility, trust in subordinates, effort, loyalty and hard work as these are life line of an organization for continuous improvement. Athar, Shahzad, Ahmad, and Ijaz (2016) argued that the ultimate message of Qur'ān and Sunnah instructs and orders the best of ethics in social as well as economic life of an individual. Qur'ān (3:110) says, "You are the best of peoples, evolved for mankind, enjoining what is right, forbidding what is wrong, and believing in Allah and let there be from you a group inviting to all to that is good, enjoining what is right ( $m a^{6} r \bar{u} f$ ) and forbidding what is wrong (munkar)". Abdi, Nor, and Radzi (2014) investigated the influence of IWE on job performance and organizational commitment and found that IWE had significant positive impact on the job performance. They argued that organizations must emphasize on implementation of IWE to safeguard continuous progression and prosperity. Ali (1988) and Al-Kazemi and Ali (2002) also suggested that for successful growth and development of Muslim societies, implementation of IWE is much necessary.

According to Rego et al. (2007) when employees feel that organization provides opportunities for their better inner life, employees, in response, develop great loyalty, commitment, effort and productivity, thus contributing to better organizational performance. Andrisani 
and Parnes (1983) also suggested that work ethics had a significant positive impact on job performance and the level of job satisfaction of employees. After thorough study of existing literature moderating role of IWE was not to be empirically tested between the relationship of inner life and employees' performance. Therefore, following hypothesis has been developed to explore this relationship.

H4: IWE moderate the relationship between inner life and employees' performance in such a way that the relationship is stronger when IWE are high.

\section{Moderating Role of IWE between Meaningful Work and Employee's Performance}

Sadozai, Marri, Zaman, Yousufzai, and Nas (2013) investigated the IWE as moderator due to the reason that the same provide guidelines to believer of Islam, which influence and enhances their capability to perform at workplace. Findings of study revealed that employees working at public organizations in Pakistan are enthusiastic with the idea of implementing Islamic ethics at workplace and found a positive and increased employees' outcome with lesser rate of turnover in all type of organizations.

Bowie (1998) followed by Immanuel Kant argued that any work can only be considered meaningful when it is done without undue pressures providing employees to perform with independence and empowerment which, in turn, enhances their capacity, get sufficient salary along with moral development. Al-Aidaros, Shamsudin, and Idris (2013) argued that IWE are set of complete and truthful values that moderate the association of different factors involved. Islamic perspective of ethics covers all aspects of human life including spiritual, physical and moral doing of individual and collective concerns. Therefore, following hypothesis has been developed to explore this relationship between the meaningful work and employees' performance.

H5: IWE moderate the relationship between meaningful work and employees' performance in such a way that the relationship is stronger when IWE are high.

\section{Moderating Role of IWE between Sense of Community and Employees' Performance}

Sanders, Hopkins, and Geroy (2004), argues that individuals gain identification when they help each other within the organization to achieve larger interest and objectives of the organization. Thus, creating such environment in the organization that makes organizational atmosphere friendly for employees so that they remain interconnected and its implementation in true sense is the core responsibility of organizational leaders. Scholars further argue that employees' behavior and attitude are strongly influenced by existence of IWE which help them to distinguish the right and wrong doings at workplace (Ghorbani et al., 2014). According to Abbasi and Rana (2012), attitude of involvement in unethical activities is one of the reasons of unproductive and unsuccessful activities at workplace as employees with such behavior accomplish their decisive anticipated comforts out of greed and selfishness (Ajmal \& Irfan, 2014).

Implementation of IWE at workplace is pivotal as performance of individuals acting upon the IWE is much higher as compared to those of unethical one. It suggests a significant positive influence of IWE on organizational performance and job performance (Mohammed, 
2005). After thorough study of existing literature moderating role of IWE was not found in relationship between the sense of community and employees' performance, thus following hypothesis is explored:

H6: IWE moderate the relationship between sense of community and employees' performance in such a way that the relationship is stronger when IWE are high.

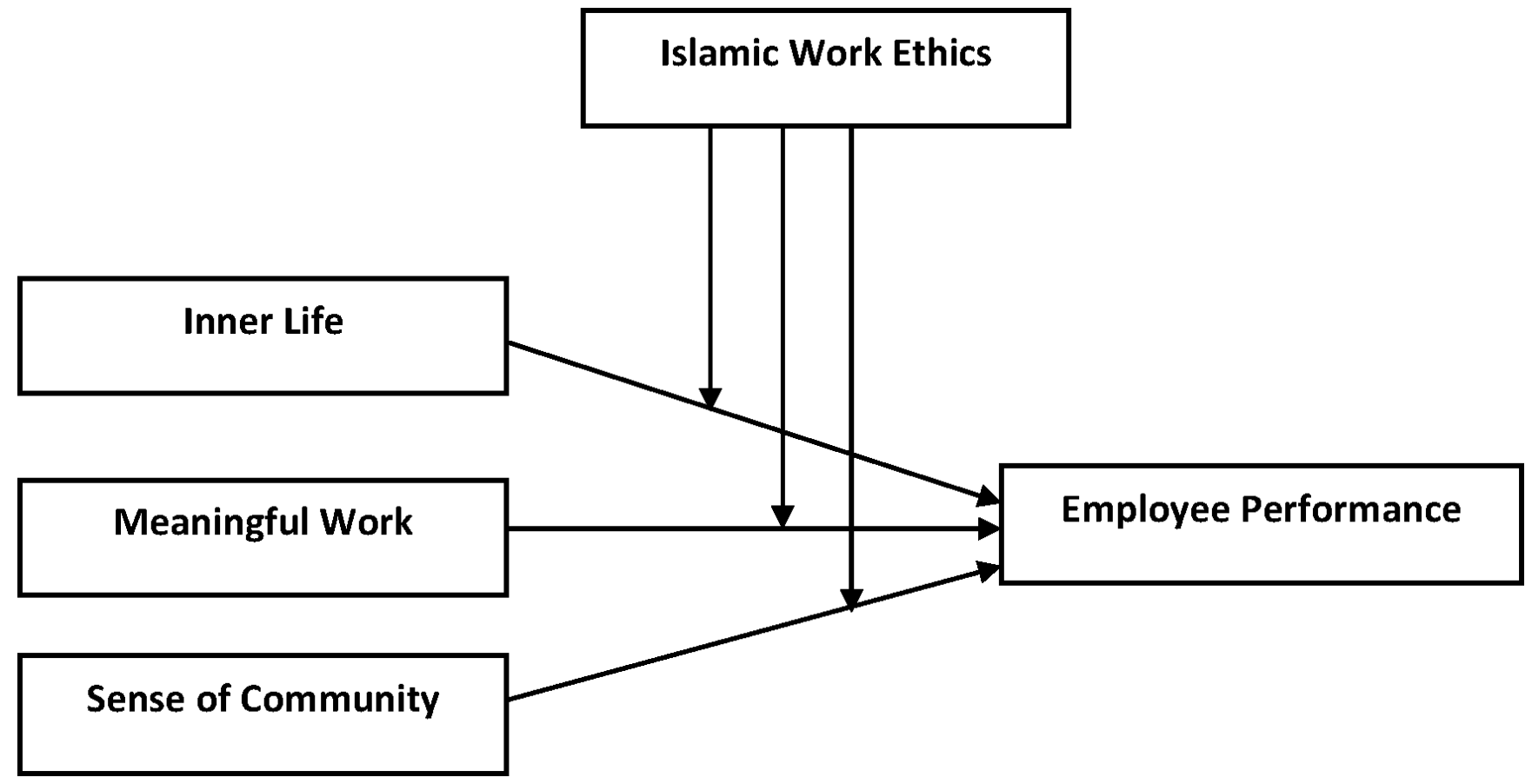

FIGURE 1. Conceptual Framework

\section{RESEARCH METHODOLOGY}

The quantitative research method was applied by conducting a relational survey (Kerlinger $\&$ Lee, 2000) design through self-administered questionnaire to explore the degree of association among variables (Wiersma \& Jurs, 2005). The selected respondents were middle line managers because of their linkage with personnel from top and bottom sides in geographically spread Islamic banks across major cities of Pakistan (Usman \& Danish, 2010). Due to specific focus on serving middle line managers, the non-probability sampling technique known as convenience sampling was executed (Battaglia, 2008). Thus, sample size of 347 fully responded questionnaires was considered out of the targeted 480, yielding a sufficient response rate of $72.29 \%$ (Singleton \& Straits, 2005). Therefore, Islamic banks in major cities including Islamabad, Rawalpindi, Lahore and Faisalabad executing general banking facilitation to target clients were considered.

Moreover, the demographics of middle line managers were controlled in accordance with finding by Allworth and Hesketh (1999) to seek impartial feedback regarding variables under study. The descriptive statistics of respondents' demographics depict that the respondents possessed sufficient experience, qualification, age with mostly male dominance and married status to provide sufficient feedback on variables under study. The adopted and 
adapted questionnaires measured on likert scale along-with results extracted from SPSS 21 analysis are as under:

Inner life has been measured using a five-item scale based on the studies by Ashmos and Duchon (2000). A sample item is "I feel hopeful about life". The Cronbach's alpha of the instrument is .77. Meaningful work has been measured using a seven-item instrument based on the studies by Ashmos and Duchon (2000). A sample item is "I experience joy in my work". The internal consistency reliability of meaningful work is .84 . Sense of community has been measured on nine items scale adopted from Ashmos and Duchon (2000). A sample item is "My immediate work unit cares about whether my spirit is energized by my work". The alpha reliability of sense of community is .79. IWE has been measured through seventeen item instrument adopted from Ali (1992). A sample item is "Life has no meaning without Work". The Cronbach's alpha of IWE is .70. Employees' performance has been measured with eight item instrument based on the studies of Tessema and Soeters (2006). Sample item from this scale included "My performance is better than my colleagues with similar qualification". The internal consistency reliability of employees' performance is .84 .

\section{RESULTS}

TABLE 1

Reliability and Correlation Analysis of Variables

\begin{tabular}{llllll}
\hline \hline Variables & 1 & 2 & 3 & 4 & 5 \\
\hline 1 IN & $(.60)$ & & & & \\
$2 \mathrm{MW}$ & $.102^{* *}$ & $(.77)$ & & & \\
$3 \mathrm{SOC}$ & $.117^{*}$ & $.649^{* *}$ & $(.80)$ & & \\
$4 \mathrm{IWE}$ & $.034^{*}$ & $.049^{*}$ & .110 & $(.78)$ \\
$5 \mathrm{EP}$ & $.113^{*}$ & $.502^{* *}$ & $.497^{* *}$ & $.193^{* *}$ & $(.84)$ \\
\hline \hline IN = Inner life, MW $=$ Meaningful work, SOC $=$ Sense of \\
Community, IWE $=$ Islamic Work Ethics, EP $=$ Employees' \\
Performance, ns = not significant, ${ }^{*} p<.05,{ }^{* *} p<.01$, \\
alpha reliabilities in brackets, $n=347$
\end{tabular}

Table 1 reports the reliability and correlation analysis of the study variables. The values possess sufficient reliabilities, in accordance with Warmbrod's argument (2001) to retrieve slightly low reliabilities with less number of questionnaire's items against respective variables. Moreover, the correlation coefficients are not more than 65\%, representing appropriate association among study variables, as per predicted hypothesis. 
TABLE 2

Multiple Regression Analysis

\begin{tabular}{|c|c|c|c|}
\hline Predictors & Employs & es' Pe & formance \\
\hline & $\beta$ & $R^{2}$ & $\Delta R^{2}$ \\
\hline Step 1 & & & \\
\hline Control variables & & .019 & \\
\hline Step 2 & & & \\
\hline IN & $.064 \mathrm{~ns}$ & & \\
\hline MW & $.336 * * *$ & & \\
\hline SOC & $.301 * * *$ & .312 & $.293 * * *$ \\
\hline
\end{tabular}

Table 2 represents predicted effect of independent variables on dependent variable through multiple regression analysis. Initially the demographics were controlled and showed of $R^{2}$ being $1.9 \%$ and then $\beta$ values for respective independent variables were mentioned showing unit change in dependent variable with $t$ value of 1.34, 4.18 and 4.05 and aggregate $R^{2}$ of $31.2 \%$. The significance and non-significance status against $\beta$ values clearly shows the acceptance of $\mathrm{H} 2$ and $\mathrm{H} 3$ with rejection of $\mathrm{H} 1$.

Moreover, the $F$ value is 48.071 showing goodness of fit, Durbin Watson $=1.866$ showing independence of data as values lie between 1.5 to 2.5; Value of Tolerance lies above .20; Variance Inflation Factor (VIF) is less than 2.5; PP plot values for dependent variable lie on the normality line, in accordance with Garson (2012) recommendations to analyze multicollinearity, normality of data and data independence.

TABLE 3

Moderated Regression Analysis

\begin{tabular}{|c|c|c|c|}
\hline \multirow[t]{2}{*}{ Predictors } & \multicolumn{3}{|c|}{ Employees' Performance } \\
\hline & $\beta$ & $R^{2}$ & $\Delta R^{2}$ \\
\hline \multicolumn{4}{|l|}{ Step 1} \\
\hline \multirow{2}{*}{\multicolumn{4}{|c|}{ Step 2}} \\
\hline & & & \\
\hline IN & $.061 \mathrm{~ns}$ & & \\
\hline MW & $.351 * * *$ & & \\
\hline SOC & $.274 * * *$ & & \\
\hline IWE & $.193 * * *$ & .338 & $.319 * * *$ \\
\hline \multicolumn{4}{|l|}{ Step 3} \\
\hline $\mathrm{IN} \times \mathrm{IWE}$ & $-.002 \mathrm{~ns}$ & & \\
\hline $\mathrm{MW} \times \mathrm{IWE}$ & $.025 * *$ & & \\
\hline $\mathrm{SOC} \times \mathrm{IWE}$ & $.016^{*}$ & .359 & $.020 * *$ \\
\hline
\end{tabular}


Table 3 represents moderated regression analysis. Initially the demographics were controlled showing $R^{2}=1.9 \%$; then $\beta$ values for respective independent variables and moderator were mentioned showing unit change in dependent variable with $t$ value of 1.30, 4.44, 3.74 and 3.66 and aggregate $R^{2}=33.8 \%$. After that interaction terms were regressed; it depicts the significance and non-significance status against $\beta$ values and $\Delta R^{2}$ of $2.0 \%$, clearly showing the acceptance of $\mathrm{H} 5$ and $\mathrm{H} 6$ with rejection of $\mathrm{H} 4$.

Moreover, the $F$ value is 40.743 showing goodness of fit, Durbin Watson $=1.91$ showing independence of data as values lies between 1.5 to 2.5; Value of Tolerance lies above .20, VIF is less than 2.5; PP plot values for dependent variable lie on the normality line. This is in accordance with Garson (2012) recommendations to analyze multicollinearity, normality of data and data independence. The interaction plots are mentioned below for consideration of high and low value of moderator, accordingly:
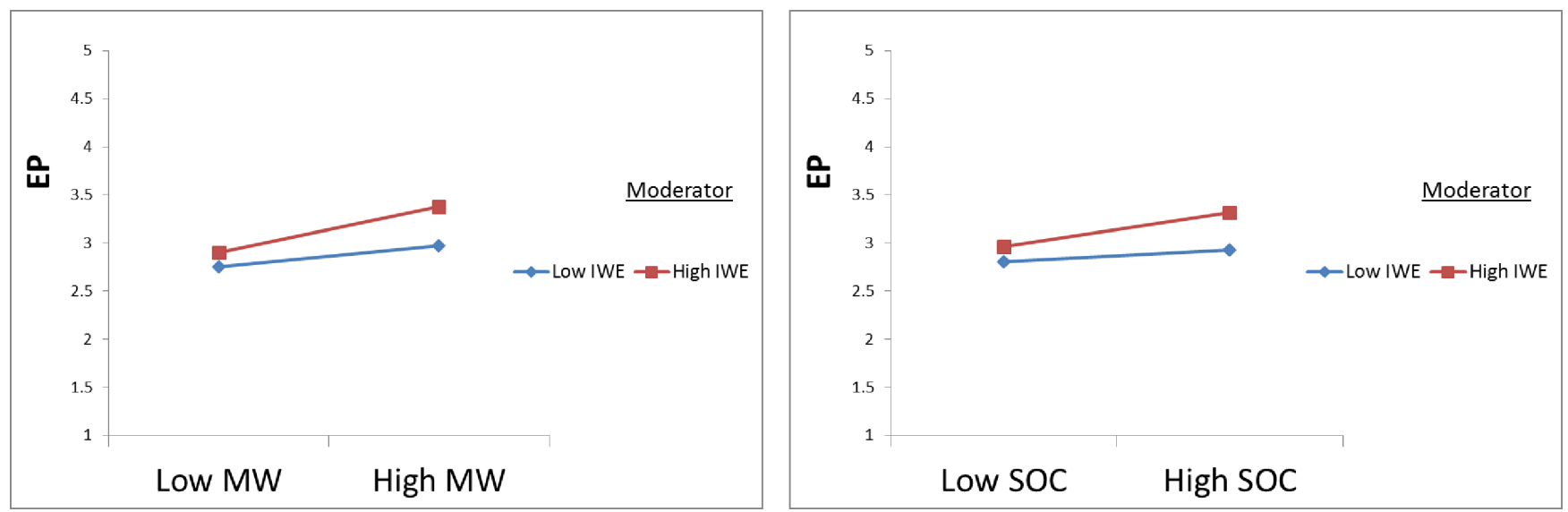

FIGURE 2. Interaction plots

\section{DISCUSSION}

Based on Aristotle's Virtue Ethics theory (Sherman, 1989) and Expectancy theory of motivation (Vroom, 1964) this study has pursued to determine the impact of work place spirituality on employees' performance with IWE as moderator. Empirical evidence supported most of the proposed hypothesis of the present study.

The first hypothesis of study that inner life is positively associated with employees' performance (H1) was not supported. This result is not in line with past empirical studies that indicated that the employees emotionally attached with such organizations that allow them to exhibit their inner self, perform beyond the call of duty. This contradictory result is due to the fact that Pakistan is a collectivist society (Hofstede, 2011) and socio-economic conditions of Pakistan remain unstable. Moreover, In Pakistan, mostly there is only one earning hand in family. Thus, for livelihood individuals have adopted a materialist approach towards life and work, and as such they are tilted more towards monetary gains and acquisition of resources a part from spiritual gains. Thus, according to conservation of resources theory (Hobfoll, 1989), individuals drive into psychological stress that might occur in three instances, namely when there is a threat of a loss of resources, an actual net loss of resources, and a lack of gained resources following the spending of resources. 
Therefore, in this perspective, employees in a state of stress spend all of their time in management of resources and pay less attention towards performance and other ethical values at workplace. Moreover, in Islamic banking sector, the middle line managers are sometimes overburdened due to irrational business targets and threats with regard to loss of job given by the management of private sector banks, family work conflicts and resources deficiency. The individuals feel stressed and they even don't have proper time to exhibit spirituality at workplace. As per expectancy theory of motivation, individuals adopt a selective behavior because they are motivated to adopt it (Vroom, 1964). Thus at workplace middle line managers have adopted a behavior of self-centeredness due to the prevailing circumstances and their overall focus is on strengthening their financial health.

While investigating the impact of meaningful work on employee performance $(\mathrm{H} 2)$, the relationship has been found though positive, but relatively weak. Here, the results are in line with the findings of Bowie (1998), who also established that meaningful activities at workplace create interest in job, and organizations earn more due to higher level of job performance. Similarly, Wrzesniewski (2003) found that the employees, who drive the most meaning from their work, i.e., feel called to their jobs experience higher job satisfaction; and because job satisfaction is often linked to performance, there could be a relationship between work performance and workers who see their work as "calling". Long and Mills (2010) also argued that for the prosperity of both individuals as well as organizations focus on workplace spirituality is significant and necessary. Moreover, as per expectancy theory of motivation (Vroom, 1964), individuals will behave or act in a certain way because they are motivated to select a specific behavior over other. Thus, in Islamic banking industry, employees find their work meaningful which enables them to be motivated to perform better by participating in organizational activities for achieving the overall goals of the organization.

Significant positive relationship has been found between sense of community and employees' performance; thus $\mathrm{H} 3$ is supported. This result is in line with past empirical studies and indicates that a direct relationship exists between sense of community and job performance of employees (McMillan \& Chavis, 1986). Similarly, few scholars have argued that for future organizational life and social change, spirituality, aspiration for meaningful work and employee's job satisfaction are critical elements (Giacalone \& Jurkiewicz, 2003; Karakas, 2009). In support, Komala and Ganesh (2007) in an empirical study stated that individual spirituality at work has a significant positive impact on job satisfaction. Therefore, it can be revealed from the results that to participate and grow in a society, employees require an environment where they are connected like a family, an atmosphere free from greed, personal gains and politics, to gain maximum return for every individual which might be available in Islamic banking industry following the principals of Islamic Sharī'ah.

Moderating role of IWE in the relationship between inner life and employee's performance $(\mathrm{H} 4)$ was found insignificant as per the results of the data set of present study. Basically, as no significant relationship was found between inner life and employee's performance, thus the presence of IWE do not change the mind set of employees and they are busy in monetary gains without taking into consideration the IWE. Moreover as per conservation of resource theory (Hobfoll, 1989), the management and acquisition of resources 
ultimately results in job burnout, as it directly affect one's mood and inner life. Although, appropriate IWE stimulate performance with much inner strength (Gocen \& Ozgan, 2018), but the present results depict that lacking of inner life satisfaction affects IWE consideration as well. Thus, IWE related principles have no impact on individuals that are already working with stressed mind (Wahab, 2017). The results are also not in line with Aristotle's virtue ethics theory that emphasizes virtue and moral characters more as compared to duties and rules (Sherman, 1989). But, as a few norms of conventional banking still prevail in Islamic banking sector, employees focus more on fulfilling their respective duties without taking into consideration the ethical concerns. The same fact is supported in other service oriented occupations, wherein spirituality at workplace was tested, resulting in non-significant association against desired performance (Sarmad \& Bashir, 2016)

The results for the moderating effect of IWE in the relationship between meaningful work and employees' performance (H5) are as expected. Thus, the observed positive relationship between meaningful work and employees' performance is stronger when IWE are high. Khan, Abbas, Gul, and Raja (2015) indicated that according to IWE, the organizational goals are considered as moral obligations and it's the responsibility of employees to achieve them even in stressful situations. Vasconcelos (2009) indicated that employees' perceptions, behaviors and decisions are influenced by tenets of religion. Moreover, in accordance with Aristotle's virtue ethics theory more emphasis is given on virtue and ethical principles in comparison to obligations and responsibilities (Sherman, 1989). Thus, McCarty (2007) also argued that the participants had reported very interesting results from prayer meetings, which ultimately increased employee morale and productivity, and decreased employee turnover. Therefore, in Islamic banking industry when IWE are high, employees are engaged in meaningful activities at workplace and work in accordance with Islamic principles that ultimately results in job satisfaction and higher performance.

The results for the moderating effect of IWE in the relationship between sense of community and employee's performance (H6) are in accordance with expectations and thus moderation is found significant. Following the virtue ethics theory of Aristotle as conceptual foundation, this study discovers that exhibition of sense of community at workplace can be managed by implementation of IWE (Sherman, 1989). Rizk (2008) argued that IWE is a way to do a job and consider work as significant strength in the life of an employee. It has direct significant association with employees' performance (Jalil, Azam, \& Rahman, 2010). IWE help in raising level of satisfaction of employees making them more committed and devoted towards work. The appropriate level of performance is pursued, since employees are supported in accordance to the principals laid down in the Sharī'ah. Thus, employees' focus on IWE is augmented to cover-up and balance any lack in interconnectedness among co-workers at workplace to maintain and achieve better performance.

\section{Practical Implications}

The findings of this study have clear implications for policymakers and higher management that can be helpful in attaining Islamic banking goals in terms of performance not only at individual level but also at organizational level as a shared vision. As IWE and workplace 
spirituality play a pivotal role in terms of performance, so orientation of staff as well as management is recommended to attain continuous benefits with keen focus on employees' inner life experiences to sustain and to progress towards common vision in Islamic banking.

The management at Islamic banks should understand that the concepts of acceptance and affection within the context of affiliation develop individual's inner peace, which supports progress and has direct impact on employees' performance. Similarly management of Islamic banks should pursue trainings for spiritual development across all quarters for better performance of employees.

\section{Limitations and Directions for Future Research}

The main limitations are that the data was collected form a single source (i.e., questionnaire); thus, there is a potential for common method bias and generalization of study. Multiple data sources might be consider by future researchers to remove possible biases. Apart from middle management, the participants with minimal work experience and senior management with extensive life experiences may be considered to get much better insight of this concept. Furthermore, as workplace spirituality and employees' performance are qualitative constructs as well, therefore, qualitative approach may be used to better quantify the effects of workplace spirituality on performance measures of employees as well as organization. The sample size may be increased to sustain validity of measurement model in all perspectives.

Further research is suggested by extending the investigation to blue color employees, considering a special pillar in organizational growth. Such working class is an integral, but under privileged part of any organizations. Combining them with white color employees will not only disclose interesting facts regarding their perception about IWE and workplace spirituality, but also give them confidence to work in organization with whole self.

\section{REFERENCES}

Abbasi, A. S., \& Rana, A. H. (2012). Impact of Islamic work ethics, reward system and organizational environment on citizenship behavior of employees. Science InternationalLahore, 24(4), 513-519.

Abdi, M. F., Nor, S. F. D. W. M., \& Radzi, N. Z. M. (2014). The impact of Islamic work ethics on job performance and organizational commitment. In Proceedings of 5th AsiaPacific Business Research Conference, Kuala Lumpur, Malaysia.

Ajmal, M. U., \& Irfan, S. (2014). Understanding the moderating role of Islamic work ethics between job stress and work outcomes. IOSR Journal of Business and Management, 16(1), 62-67. doi: https://doi.org/10.9790/487X-16146267

Al-Aidaros, A. H., Shamsudin, F. M., \& Idris, K. M. (2013). Ethics and ethical theories from an Islamic perspective. International Journal of Islamic Thought, 4, 1-13. doi: https://doi.org/10.24035/ijit.04.2013.001

AL-Arimi, A. A., Masrom, M., \& Mahmood, N. H. N. (2016). The moderating effect of Islamic work ethics on the relationship between knowledge management capabilities 
and organizational performance at the private higher education institutions in Oman. Journal of Theoretical $\mathcal{F}$ Applied Information Technology, 94(2), 396-407.

Ali, A. (1988). Scaling an Islamic work ethic. The Journal of Social Psychology, 128(5), 575-583. doi: https://doi.org/10.1080/00224545.1988.9922911

Ali, A. J. (1992). The Islamic work ethic in Arabia. The Journal of Psychology, 126(5), 507-519. doi: https://doi.org/10.1080/00223980.1992.10543384

Ali, A. J., \& Al-Owaihan, A. (2008). Islamic work ethic: A critical review. Cross Cultural Management: An International Journal, 15(1), 5-19.

doi: https://doi.org/10.1108/13527600810848791

Al-Kazemi, A. A., \& Ali, A. J. (2002). Managerial problems in Kuwait. Journal of Management Development, 21(5), 366-375.

doi: https://doi.org/10.1108/02621710210426853

Allworth, E., \& Hesketh, B. (1999). Constructoriented biodata: Capturing changerelated and contextually relevant future performance. International Journal of Selection and Assessment, 7(2), 97-111. doi: https://doi.org/10.1111/1468-2389.00110

Altaf, A., \& Awan, M. A. (2011). Moderating affect of workplace spirituality on the relationship of job overload and job satisfaction. Journal of Business Ethics, 104(1), 93-99. doi: https://doi.org/10.1007/s10551-011-0891-0

Andrisani, P., \& Parnes, H. (1983). Commitment to the work ethic and success in the labor market: A preview of research findings. In J. Barbash, R. J. Lampman, S. A. Levitan, \& G. Tyler (Eds.), The work ethic - A critical analysis (pp. 101-120). Madison, WI: IRRA.

Ashmos, D. P., \& Duchon, D. (2000). Spirituality at work: A conceptualization and measure. Journal of Management Inquiry, 9(2), 134-145.

doi: https://doi.org/10.1177/105649260092008

Athar, M. R., Shahzad, K., Ahmad, J., \& Ijaz, M. S. (2016). Impact of Islamic work ethics on organizational commitment: Mediating role of job satisfaction. Journal of Islamic Business and Management, 6(1), 397-416.

Battaglia, M. P. (2008). Nonprobability sampling, encyclopedia of survey research methods. New York, NY: Sage Publications.

Bowie, N. E. (1998). A Kantian theory of meaningful work. Journal of Business Ethics, 17(9), 1083-1092. doi: https://doi.org/10.1023/A:1006023500585

Brandt, E. (1996). Corporate pioneers explore spirituality peace. HR Magazine, 41(4), 82-87.

Burack, E. H. (1999). Spirituality in the workplace. Journal of Organizational Change Management, 12(4), 280-292. doi: https://doi.org/10.1108/09534819910282126

Cacioppe, R. (2000). Creating spirit at work: Re-visioning organization development and leadership-Part I. Leadership E Organization Development Journal, 21(1), 48-54. doi: https://doi.org/10.1108/01437730010310730

Cavanagh, G. F. (1999). Spirituality for managers: Context and critique. Journal of Organizational Change Management, 12(3), 186-199. doi: https://doi.org/10.1108/09534819910273793 
Chappell, T. (1993). The soul of a business: Managing for profit and the common good. Des Plaines, IL: Bantam.

Driver, M. (2005). From empty speech to full speech? Reconceptualizing spirituality in organizations based on a psychoanalytically-grounded understanding of the self. Human Relations, 58(9), 1091-1110. doi: https://doi.org/10.1177/0018726705059038

Duchon, D., \& Plowman, D. A. (2005). Nurturing the spirit at work: Impact on work unit performance. The Leadership Quarterly, 16(5), 807-833.

doi: https://doi.org/10.1016/j.leaqua.2005.07.008

Fry, L. W. J. (2013). Spiritual leadership and faith and spirituality in the workplace. In Handbook of faith and spirituality in the workplace (pp. 697-704). New York, NY: Springer. doi: https://doi.org/10.1007/978-1-4614-5233-1_38

Garcia-Zamor, J. C. (2003). Workplace spirituality and organizational performance. Public Administration Review, 63(3), 355-363. doi: https://doi.org/10.1111/1540-6210.00295

Garson, G. D. (2012). Testing statistical assumptions. Asheboro, NC: Statistical Associates Publishing.

Giacalone, R. A., \& Jurkiewicz, C. L. (2003). Right from wrong: The influence of spirituality on perceptions of unethical business activities. Journal of Business Ethics, 46(1), 85-97. doi: https://doi.org/10.1023/A:1024767511458

Gocen, A., \& Ozgan, H. (2018). An analysis of workplace spirituality debates. Universal Journal of Management, 6, 70-79. doi: https://doi.org/10.13189/ujm.2018.060204

Hobfoll, S. E. (1989). Conservation of resources: A new attempt at conceptualizing stress. American Psychologist, 44(3), 513-524.

doi: https://doi.org/10.1037/0003-066X.44.3.513

Hofstede, G. (2011). Dimensionalizing cultures: The Hofstede model in context. Online Readings in Psychology and Culture, 2(1), 1-26. doi: https://doi.org/10.9707/23070919.1014

Jalil, A., Azam, F., \& Rahman, M. K. (2010). Implementation mechanism of ethics in business organizations. International Business Research, 3(4), 1-11. doi: https://doi.org/10.5539/ibr.v3n4p145

Karakas, F. (2009). New paradigms in organizational development in the 21st century: Positivity, spirituality, and complexity. Organization Development Journal, 27(1), 1126.

Kerlinger, F. N., \& Lee, H. B. (2000). Foundations of behavioral research. Boston, MA: Harcourt Publishers.

Khan, K., Abbas, M., Gul, A., \& Raja, U. (2015). Organizational justice and job outcomes: Moderating role of Islamic work ethic. Journal of Business Ethics, 126(2), 235-246. doi: https://doi.org/10.1007/s10551-013-1937-2

Komala, K., \& Ganesh, L. S. (2007). Individual spirituality at work and its relationship with job satisfaction and burnout: An exploratory study among healthcare professionals. The Business Review, 7(1), 124-129.

Krishnakumar, S., \& Neck, C. P. (2002). The "what", "why" and "how" of spirituality in the workplace. Journal of Managerial Psychology, 17(3), 153-164.

doi: https://doi.org/10.1108/02683940210423060 
Laabs, J. J. (1995). Balancing spirituality and work. Personnel Journal, 74(9), 60-68.

Long, B. S., \& Mills, J. H. (2010). Workplace spirituality, contested meaning, and the culture of organization: A critical sensemaking account. Journal of Organizational Change Management, 23(3), 325-341.

doi: https://doi.org/10.1108/09534811011049635

Malphurs, A. (2004). Values-driven leadership: Discovering and developing your core values for ministry. Grand Rapids, MI: Baker Books.

McCarty, W. B. (2007). Prayer in the workplace: Risks and strategies to manage them. Business Renaissance Quarterly, 2(1), 97-105.

McMillan, D. W., \& Chavis, D. M. (1986). Sense of community: A definition and theory. Journal of Community Psychology, 14(1), 6-23. doi: https://doi.org/10.1002/15206629(198601)14:1<6::AID-JCOP2290140103>3.0.CO;2-I

Miller, L. (1998). After their checkup for the body, some get one for the soul. The Wall Street Journal, 20, A1-A6.

Mirvis, P. H. (1997). Crossroads "soul work" in organizations. Organization Science, 8(2), 192-206. doi: https://doi.org/10.1287/orsc.8.2.192

Mohammed, A. (2005). The relationship between Islamic rules and accountants' ethics (Unpublished manuscript). Hadhramout, Yemen.

Morse, N. C., \& Weiss, R. S. (1955). The function and meaning of work and the job. American Sociological Review, 20(2), 191-198. doi: https://doi.org/10.2307/2088325

Nandan-Prabhu, K. P., Rodrigues, L. L. R., \& Kumar, K. R. (2016). Workplace spirituality: A review of approaches to conceptualization and operationalization. Purushartha, 9(2), $1-17$.

Ozgan, H. (2017). Workplace spirituality scale: Validity and reliability study. Transylvanian Review, 1(8). Retrieved from https://bit.ly/2XsLGmM

Paloutzian, R. F., Emmons, R. A., \& Keortge, S. G. (2003). Spiritual well-being, spiritual intelligence, and healthy workplace policy. In Handbook of workplace spirituality and organizational performance. Oxford, UK: Routledge.

Petchsawanga, P. \& Duchan, D. (2012). Workplace spirituality, mediation and work performance. Journal of Management, Spirituality $\mathcal{E}$ Religion, 9(2), 189-208.

doi: https://doi.org/10.1080/14766086.2012.688623

Pfeffer, J., \& Veiga, J. F. (1999). Putting people first for organizational success. Academy of Management Perspectives, 13(2), 37-48.

doi: https://doi.org/10.5465/ame.1999.1899547

Rachels, J. \& Rachels, S. (1993). The elements of moral philosophy. New York, NY: McGraw-Hill.

Rizk, R. R. (2008). Back to basics: An Islamic perspective on business and work ethics. Social Responsibility Journal, 4(1/2), 246-254.

doi: https://doi.org/10.1108/17471110810856992

Reave, L. (2005). Spiritual values and practices related to leadership effectiveness. The Leadership Quarterly, 16(5), 655-687. doi: https://doi.org/10.1016/j.leaqua.2005.07.003 
Rego, A., \& Cunha, M. P. (2008). Workplace spirituality and organizational commitment: An empirical study. Journal of Organizational Change Management, 21(1), 53-75. doi: https://doi.org/10.1108/09534810810847039

Rego, A., Cunha, M. P., \& Souto, S. (2007). Workplace spirituality, commitment, and selfreported individual performance: An empirical study. Management Research: Journal of the Iberoamerican Academy of Management, 5(3), 163-183. doi: https://doi.org/10.2753/JMR1536-5433050303

Sadozai, A. M., Marri, M. Y. K., Zaman, H. M. F., Yousufzai, M. I., \& Nas, Z. (2013). Moderating role of Islamic work ethics between the relationship of organizational commitment and turnover intentions: A study of public sector of Pakistan. Mediterranean Journal of Social Sciences, 4(2), 767-775.

Sanders III, J. E., Hopkins, W. E., \& Geroy, G. D. (2004). Spirituality-leadership-commitment relationships in the workplace: An exploratory assessment. In Academy of Management Proceedings, Academy of Management, Briarcliff Manor, NY.

Sarmad, M., \& Bashir, S. (2016). Impact of nurses' personality on patients' satisfaction; An occupational focus on spirituality at work as moderator. Abasyn University Journal of Social Sciences, 9(1), 69-85.

Sherman, N. (1989). The fabric of character: Aristotle's theory of virtue. Oxford, UK: Clarendon Press.

Singleton, R. A., \& Straits, B. C. (2005). Approaches to social research (4th ed.). New York, NY: Oxford University Press.

Tessema, M. T., \& Soeters, J. L. (2006). Challenges and prospects of HRM in developing countries: Testing the HRM-performance link in the Eritrean civil service. The International Journal of Human Resource Management, 17(1), 86-105.

doi: https://doi.org/10.1080/09585190500366532

Tischler, L., Biberman, J., \& McKeage, R. (2002). Linking emotional intelligence, spirituality and workplace performance: Definitions, models and ideas for research. Journal of Managerial Psychology, 17(3), 203-218.

doi: https://doi.org/10.1108/02683940210423114

Usman, A., \& Danish, R. Q. (2010). Spiritual consciousness in banking managers and its impact on job satisfaction. International Business Research, 3(2), 65-72.

doi: https://doi.org/10.5539/ibr.v3n2p65

Vasconcelos, A. F. (2009). Intuition, prayer, and managerial decision-making processes: A religion-based framework. Management Decision, 47(6), 930-949.

doi: https://doi.org/10.1108/00251740910966668

Vroom, V. H. (1964). Work and motivation (Vol. 54). New York, NY: Wiley.

Wabba, M. A., \& House, R. J. (1974). Expectancy theory in work and motivation: Some logical and methodological issues. Human Relations, 27(2), 121-147.

doi: https://doi.org/10.1177/001872677402700202

Wahab, M. A. (2017). Investigating the nexus between personality traits and Islamic work ethics. Asian Academy of Management Journal, 22(1), 183-213.

doi: https://doi.org/10.21315/aamj2017.22.1.8 
Warmbrod, J. R. (2001). Conducting, interpreting, and reporting quantitative research. New Orleans, LA: Research Pre-Session.

Wiersma, W., \& Jurs, S. (2005). Research methods in education: An introduction (8th ed.). Boston, MA: Allyn and Bacon.

Wrzesniewski, A. (2003). Finding positive meaning in work. In Positive organizational scholarship: Foundations of a new discipline. San Francisco, CA: Berrett-Koehler Publishers.

Zafar, J. (2010). Measuring religiosity and workplace spirituality in Pakistan: A case study of armed forces and university teachers. Cross-Cultural Communication, 6(4), 104111. 